\title{
The relationship between sole curvature of roll over footwear and changes in gait
}

\author{
Saeed Forghany ${ }^{1,2}$, Christopher Nester $^{1 *}$, Barry Richards ${ }^{1}$ \\ From 3rd Congress of the International Foot and Ankle Biomechanics Community \\ Sydney, Australia. 11-13 April 2012
}

\section{Background}

Footwear with a curved sole profile remains popular and there is evidence of its effects on gait and posture [1,2]. Existing literature describes how different styles of roll over footwear affect gait, although the effects of the precise radii of the curve of the sole on the gait rocker function and other reported effects have not been investigated. The aim of this study was to relate the radii of the soles of two roll over footwear products to their effects on walking.

\section{Materials and methods}

Lower limb kinematic and GRF data was collected from twenty subjects during walking in four footwear conditions: flat control shoe, weighted flat control shoe, the new prototype rollover shoe and a MBT shoe. The static sole radii of all footwear was calculated for all and distinct parts of the sole, and correlated with radii of the gait rollover shapes as described by Hansen et al $[3,4]$.

\section{Results}

The radii of the foot-shoe roll-over shapes were significantly changed in response to different shoe conditions $(\mathrm{p}<0.001)$, but leg and thigh radii were not. The MBT shoes demonstrated a low positive correlation between the radius of foot-shoe roll-over shape and the static sole radii (whole sole) $(\mathrm{r}=0.32 ; \mathrm{p}=0.04)$ and the radii of the heel area of the sole $(r=0.39 ; p=0.01)$. The new prototype shoes showed no statistically significant correlations.

\section{Conclusion}

The results of this study indicate that the static curve of the sole is not the main factor influencing gait. It

\footnotetext{
* Correspondence: c.j.nester@salford.ac.uk

${ }^{1}$ School of Health Sciences, University of Salford, UK

Full list of author information is available at the end of the article
}

appears that the extent to which the curved sole deforms dynamically during gait (i.e. shoe bending stiffness) influences the strength of the relationship between sole curvature and changes in gait.

\section{Author details \\ ${ }^{1}$ School of Health Sciences, University of Salford, UK. ${ }^{2}$ Musculoskeletal Research Centre, School of Rehabilitation Sciences, Isfahan University of Medical Sciences, Iran.}

Published: 10 April 2012

\section{References}

1. Nigg, et al: Effect of an unstable shoe construction on lower extremity gait characteristics. Clin Biomech 2006, 21:82-8.

2. Romkes, et al: Changes in gait and EMG when walking with the Masai Barefoot Technique. Clin Biomech 2006, 21:75-81.

3. Hansen, et al: Effects of shoe heel height on biologic rollover characteristics during walking. J Rehabil Res Dev 2004, 41:547-554.

4. Hansen, et al: Effective rocker shapes used by able-bodied persons for walking and fore-aft swaying: Implications for design of ankle-foot prostheses. Gait Posture 2010, 32:181-184.

doi:10.1186/1757-1146-5-S1-O5

Cite this article as: Forghany et al:: The relationship between sole curvature of roll over footwear and changes in gait. Journal of Foot and Ankle Research 2012 5(Suppl 1):05.

Submit your next manuscript to BioMed Central and take full advantage of:

- Convenient online submission

- Thorough peer review

- No space constraints or color figure charges

- Immediate publication on acceptance

- Inclusion in PubMed, CAS, Scopus and Google Scholar

- Research which is freely available for redistribution

\section{Biomed Central}

(c) 2012 Forghany et al; licensee BioMed Central Ltd. This is an Open Access article distributed under the terms of the Creative Commons Attribution License (http://creativecommons.org/licenses/by/2.0), which permits unrestricted use, distribution, and reproduction in any medium, provided the original work is properly cited. 